\title{
Growth Hormone Therapy in Pediatric Hypercatabolic State. A Systematic Review and Meta-Analysis*
}

\author{
Terapia com Hormônio de Crescimento nos Estados \\ Hipercatabólicos em Pediatria: Revisão Sistemática e Metanálise
}

Ronaldo Arkader', Orlei Araújo², Dafne Cardoso Bourguignon da Silva'; Mario R. Hirschheimer ${ }^{1}$, Werther B. de Carvalho ${ }^{1}$

\section{RESUMO}

JUSTIFICATIVA E OBJETIVOS: Avaliar a utilização do hormônio de crescimento recombinante (rhGH) em pacientes pediátricos em estado de hipercatabolismo internados em unidades de terapia intensiva pediátrica (UTIP).

MÉTODO: Foram pesquisados os seguintes bancos de dados: MedLine (1990 a 2005), LILACS (1990 a 2005), OVID (1990 a 2006), EMBASE (1990 a 2005). Constou de estudos aleatórios controlados, em pacientes pediátricos com quadro de hipercatabolismo (queimados, sépticos) que utilizaram rhGH durante internação em UTIP. A intervenção incluía rhGH versus placebo. Os dados foram extraídos em duplicata e independentemente. A metanálise foi realizada utilizando as ferramentas estatísticas do software Review Manager, sendo utilizado o método de Mantel-Haenzel para variáveis dicotômicas e variância inversa para contínuas.

RESULTADOS: Existem evidências de que a utilização do rhGH em pacientes pediátricos queimados reduziu a utilização de albumina exógena, melhora no ganho de massa muscular magra e aceleração da cicatrização dos ferimen1. Pediatric Intensive Care Unit - Hospital e Maternidade Santa Marina
2. Pediatric Intensive Care Unit - Pronto-Socorro Hospital Infantil
Sabará

*Recebido da UTI Pediátrica do Hospital e Maternidade Santa Marina, São Paulo, SP

Apresentado em 02 de março de 2006

Aceito para publicação em 24 de março de 2006

Endereço para correspondência:

Dr. Orlei Araújo

UTI Pediátrica - Hospital e Maternidade Santa Marina

Av. Santa Catarina, 2785

04378-500 São Paulo, SP

Fone: 55 (11) 50131263

E-mail: orlei@uol.com.br

(C)Associação de Medicina Intensiva Brasileira, 2006 tos do local doador, sem efeito na mortalidade. Possivelmente, pode reduzir o tempo de internação. A hiperglicemia foi o evento adverso mais freqüente.

CONCLUSÕES: Essa revisão sugere que a aplicação precoce do rhGH no tratamento em pacientes pediátricos com queimaduras graves tem potencial implicação na melhora clínica. Embora a literatura não dê suporte à utilização de rotina, deve-se considerar sua utilização neste grupo de pacientes, pelo menos para estudos futuros. Em pacientes sépticos, os dados são insuficientes para qualquer consideração.

Unitermos: cuidados intensivos, hormônio do crescimento, metabolismo, Pediatria, queimaduras

\section{SUMMARY}

BACKGROUND AND OBJECTIVES: To assess the use of recombinant human growth hormone $(\mathrm{rGH})$ in pediatric patients with hypercatabolic state in the pediatric intensive care unit.

METHODS: We searched the databases of MedLine (1990 to 2005), LILACS (1990 to 2005), OVID (1990 to 2006) and EMBASE (1990 to 2005). Randomized controlled trials in pediatric patients using rhGH for hypercatabolic state (burns, sepsis) were selected. Intervention included rhGH therapy versus placebo. Data were extracted in duplicate and independently. Meta-analyses were performed using the software Review Manager statistic tools, with MantelHaenzel method for dichotomous outcomes and inverse variance method for continuous.

RESULTS: There were evidences that rhGH in burned pediatric patients can reduce exogenous albumin requirement, with a improvement in Lean Body Mass, and accelerate site-donor wound healing, with no effects on mortality. Possibly can reduce the length of hospital stay. Hyperglycemia was the most frequently reported adverse event.

CONCLUSIONS: This review suggests that the early application of rhGH to standard treatment in pediatric severe 
burned patients has the potential to improve some aspects from outcome. At this time, although the literature does not support routine rhGH for pediatric burn patients, consideration should be given to its use in this group, at least as an aim for further research. For use in septic patients, no proper statement can be done.

Key Words: burns, growth hormone, intensive care, metabolism, pediatrics.

\section{INTRODUCTION}

The initial "acute phase response" to any illness or injury, such as extensive surgery, multiple trauma, burns, or sepsis, is characterized by gluconeogenesis, proteolysis, and lipolysis to rapidly provide the metabolic substrates for vital organs ${ }^{1}$. Catabolism contributes substantially to morbidity and mortality of critical illness ${ }^{2}$. In spite of aggressive nutritional support, critically ill patients lose large amounts of body protein. This proteic hypercatabolism leads to severe wasting and malfunctioning of muscles and vital organs and to deficient healing. In catabolic conditions requiring new protein synthesis, prolonged suppression of growth hormone secretion may contribute to impaired wound healing, delayed recovery or atrophy of the enteral mucosa and muscle weakness ${ }^{3}$.

The anterior pituitary gland plays a crucial role in metabolic and immunologic homeostasis. Several endocrine changes have been described in severe illness, including altered growth hormone secretory pattern ${ }^{2}$. During critical illness, GH secretion is characterized by reduced pulse amplitude and elevated interpulse levels and is associated with low circulating IGF-I (insulin-like growth factor - I), and low levels of circulating insulin-like growth factor bound protein3 (IGFBP-3). These findings suggest a specific pattern of hypothalamic-pituitary function in critical illness and $\mathrm{GH}$ resistance ${ }^{4}$.

GH is a polypeptide with anabolic, lipolytic, and immunestimulating properties ${ }^{5}$. It is secreted by pituitary somatotropes in a pulsatile fashion ${ }^{6}$. GH has direct and indirect anabolic actions. The principal mediator of its indirect anabolic actions is IGF-I. GH secretion rate is dependent on age, sex, circadian rhythm and nutritional state. In the first semester of life, serum GH levels are high and IGF-I are low, when comparing to children and adults? ${ }^{7}$.

In 1999, the first randomized controlled trial with supraphysiological doses of rhGH in critically ill adult patients showed an unexpected increased mortality ${ }^{8}$. Since then, some editorials speculate the possible mechanism behind the adverse outcome in the rhGH-supplemented patients ${ }^{9}$. The unexpected results of the study by Takala et al. have generated a debate about the safety of rhGH therapy ${ }^{8}$. The use of high doses of rhGH has been questioned: the dose was 10-20 times higher than the dose used as replacement therapy in adults with $\mathrm{GH}$ deficiency ${ }^{10}$. Demling et al. suggests that rhGH should not be given to critically ill adult patients, with the exception of burn and trauma ${ }^{11}$.

Among the hormonal changes, the modulation in the $\mathrm{GH} /$ IGF-I axis in pediatric population with hypercatabolic state is not entirely clear ${ }^{12}$. Balcells et al. found a GH-resistant state in postoperative children following cardiac surgery characterized by an elevation of $\mathrm{GH}$ secretion that was not followed by IGF-I and IGFBP- $3^{13}$. His study population, however, consisted in a very heterogeneous population, with a range of age from 5 to 137 months and the GH measurement was made from urine samples. Leite et al. described that cardiac surgical stress was marked by an increase in serum GH and a decrease in serum IGF-I levels on postoperative day 2 and after this period return to preoperative serum levels ${ }^{14}$. Another study, by Onenli-Mungan et al. showed the same GH/IGF-I pattern in pediatric septic children but they observed that hypoglycemia could be a contributing factor to elevated GH levels ${ }^{15}$. Gardelis et al. also did a prospective study with septic and trauma children and found the same GH/IGF-I response in trauma and septic patients ${ }^{12}$. Huysman et al. described a suppressive effect of 2 days of dexametasone treatment on serum $\mathrm{GH}$ levels, without an acute decline in serum IGF-I levels in 10 very preterm artificially ventilated infants with bronchopulmonary dysplasia ${ }^{16}$. De Groof et al. have shown that survivor children with meningococcal sepsis during the first 48 $\mathrm{h}$ after admission demonstrated an increase in the number and amplitude of GH peaks, mean GH, free IGF-I, and IGFBP-3 levels ${ }^{17}$. They hypothesize that these changes could represent a mechanism to recover from sepsis and may point to the restoration of anabolic function. However, no surviving children with meningococcal sepsis had extremely high levels of cytokines, mean GH, and IGFBP-1, very different from levels in those who survived.

\section{METHODS}

We searched MedLine from 1990 to may 2004, EMBASE from 1990 to may 2004, LILACS from 1990 may 2004, OVID from 1990 to may 2004 for articles, using the keywords: intensive care unit, hypercatabolic, systemic inflammatory response syndrome, burn, trauma, growth hormone, recombinant human growth hormone, insulin-like growth factor-l, children and pediatric.

The following criteria were used to select articles: a) All randomized controlled trials in pediatric patients using $\mathrm{rhGH}$ for hypercatabolic state; b) the intervention included rhGH 
therapy versus placebo; and d) outcomes, like length of pediatric intensive care unit (PICU) or hospital stay, or PICU or hospital mortality, or other measures of clinical improvement.

Independently and in duplicate, two of the authors abstracted data from these trials. Information abstracted included the objective, patient population, setting, description of method used recombinant human growth hormone, outcomes, criteria and definitions used, study results, and publication status. Differences in opinion were settled by consensus or after consultation with a third investigator.

Because of heterogeneity of the studies, we initially performed both qualitative and quantitative analyses and decided to analyze the data in clinically relevant categories on the basis of similar rhGH dosing strategies when sufficient data were available. Where it was possible, meta-analyses were performed using statistic tools from the software Review Manager (The Cochrane Collaboration, 2003) ${ }^{18}$, using Mantel-Haenzel method for dichotomous outcomes and inverse variance method for continuous. All meta-analyzed studies were designed as randomized and double-blinded. Heterogeneity was reported when significant.

\section{RESULTS}

There was a great heterogeneity among studies concerning design and allocation. Most of the trials involved severely burned children (burned total body surface area $>$ $40 \%$ or third-degree burns $>20 \%$. Only 1 study involving septic children was eligible for analyses ${ }^{19}$. All trials used the subcutaneous or intramuscular rhGH administration route and the therapy was given at least for 7 days.

Effects of rhGH on donor site healing: Gilpin ${ }^{20}$ and Herndon $^{21}$ involved a total of 48 burned children in treatment group with rhGH, versus 44 placebo-controls. The treatment was effective in reducing donor-site time healing (Weighted Mean Difference: -1.77 day, $p<0.00001$ for overall effect).

Mortalitiy in burned children: This issue was addressed in 2 studies $^{22,23}$, involving a total of 61 patients in treatment groups (rhGH $0.2 \mathrm{mg} / \mathrm{kg} / \mathrm{day}$ ) and 69 in control (saline as placebo) groups. Mortality was comparable between groups (Odds Ratio 1.15 [0.15, 8.53 95\% Confidence Interval], $p=0.89$ ).

Change in lean body mass (LBM) in burned children: Two studies $^{24,25}$, with a total of 29 children treated with rhGH $0.05 \mathrm{mg} / \mathrm{kg} /$ day for at least 12 weeks after burn (versus 32 children in placebo groups), showed that accretion of LBM was increased with treatment 9 months after burn (Weighted Mean Difference: $1.14 \mathrm{~kg}, \mathrm{p}<0.0001$ for overall effect).
These studies demonstrated a highly significant heterogeneity $(p<0.00001)$ for the overall weight gain: the study of Hart et al. showed a Weighted Mean Difference in weight gain at 9 months of $3.7 \mathrm{~kg}$ for the rhGH group ${ }^{24}$, conflicting with Weighted Mean Difference of $-0.1 \mathrm{~kg}$ in the study of Suman et al. ${ }^{25}$.

Albumin substitution requirement in pediatric burned patients: Jeschke et al. ${ }^{22}$ and Ramirez et al..$^{24}$ analyzed a total of 60 patients treated with rhGH and 67 controls who received saline as placebo, and observed a remarkable reduction in albumin requirements during hospitalization (Weighted Mean Difference: -138.6 g, $p<0.00001$ for overall effect) for patients of treatment group.

Effects of rhGH on mediators of inflammatory acute phase response in burned children: Only the effects on Tumor $\mathrm{Ne}-$ crosis Factor $\alpha$ (TNF- $\alpha$ ) were eligible to analysis in 2 small studies $^{22,26}$, with a total of 23 patients in treatment groups $(0.2 \mathrm{mg} / \mathrm{kg} /$ day) and 25 patients in placebo groups. There was a greater decrease in TNF- $\alpha$ levels in rhGH group after at least 10 days of treatment ( $p<0.001$ for overall effect), when compared to placebo group.

Adverse events: Only the occurrence of hyperglycemia was available for analysis. Ramirez et al. ${ }^{23}$, reported that it was observed in 30 patients from 48 in rhGH group and 22 from 54 in placebo group. Herndon et al. reported hyperglycemia in 2 of 10 patients of rhGH group versus none in placebo group ${ }^{21}$. Hart et al..$^{24}$ reported that it was not observed in none of 19 patients in treatment group and 21 from placebo group. In the meta-analysis of these 3 studies, the Odds Ratio for occurrence of hyperglycemia was 2.56 [1.23, 5.34 95\% Confidence Interval], $p=0.01$. No significant differences were observed for organ dysfunction, septic or hemodynamic complications between rhGH and placebo ${ }^{21-24}$.

Other issues: Herndon et al. ${ }^{21}$ reported into a small randomized and double-blinded study that treatment with rhGH was able to reduce length of hospital for severely burned children (from 46 to 32 days, $p<0.05$ ). Klein et al. reported that rhGH was ineffective in improving bone formation in burned children ${ }^{27}$. In pediatric septic patients, only one study with a limited patient number has shown a small benefit in rhGH group ${ }^{19}$. However, after Takala report ${ }^{8}$, studies with this special population have not been published.

\section{DISCUSSION}

Burn-related injuries are a leading cause of morbidity and mortality in children ${ }^{28}$. Full-thickness burn wounds involve destruction of the entire dermis and epidermis and all regenerative elements can be destroyed, and healing could 
be impaired. All such injuries should therefore be excised and grafted. Early excision and grafting have been shown to reduce pain and shorten hospital stay. ${ }^{29}$ In severely burned children the systemic administration of rhGH can counter-balance the hypermetabolic response, particularly in children who have limited tissue reserve ${ }^{22}$.

The first principle of burn treatment is fluid resuscitation ${ }^{30}$. After successful resuscitation, a hypermetabolic response occurs. The goal is to eliminate unfavorable aspects of the hypermetabolic response, particularly muscle catabolism, without inadvertently harming the patient ${ }^{31}$. Pharmacologic and non-pharmacologic strategies may be used to reverse the catabolic effect of burn injury ${ }^{31}$. Nutritional support is a non-pharmacologic strategic issue and included aggressive protein supplementation and high carbohydrate diet to stimulate protein synthesis and increase endogenous insulin production ${ }^{32}$. After severe burn injury, protein degradation may be exacerbated by apparent deficiencies which manifests as profound lean body mass wasting and prolongs rehabilitation needs and length of stay ${ }^{33}$.

Pharmacologic strategies to modulate the postburn hypermetabolic response may be achieved through the administration of rhGH. Daily rhGH during acute burn care can possibly influence the hepatic acute phase response, improve muscle protein kinetics and decreased donor site healing, and also fasten re-epithelialization ${ }^{22}$. Patients receiving treatment demonstrated $100 \%$ increases in serum IGFI and IGFBP-323. Recombinant hGH has several adverse side effects, most notably hyperglycemia. An increase in mortality was not observed in severely burned children.

\section{CONCLUSIONS}

This review suggests that the early application of rhGH to standard treatment in pediatric severe burned patients has the potential to improve some aspects from outcome. At this time, although the literature does not support routine rhGH for pediatric burn patients, consideration should be given to its use in this group, at least as an aim for further research. For use in septic patients, no proper statement can be done.

\section{REFERENCES}

01. Michie HR - Metabolism of sepsis and multiple organ failure. World J Surg, 1996;20:460-464.

02. Van den Berghe G - Endocrine evaluation of patients with critical illness. Endocrinol Metab Clin North Am, 2003;32:385-410.

03. Meyer NA, Muller MJ, Herndon DN - Nutrient support of the healing wound. New Horiz, 1994;2:202-214.

04. Van den Berghe $\mathrm{G}$, de Zegher F, Lauwers P - Dopamine suppresses pituitary function in infants and children. Crit Care Med, 1994;22:1747-1753.

05. Saito $\mathrm{H}$ - Anabolic agents in trauma and sepsis: repleting body mass and function. Nutrition, 1998;14:554-556.

06. Van den Berghe G, de Zegher F, Lauwers P et al - Growth hormone secretion in critical illness: effect of dopamine. J Clin Endocrinol Metab, 1994;79:1141-1146.

07. Ogilvy-Stuart AL - Growth hormone deficiency (GHD) during birth to 2 years of age: diagnostic specifics of GHD during the early phase of life. Horm Res, 2003;60:(Suppl1):2-9.

08. Takala J, Ruokonen E, Webster NR et al - Increased mortality associated with growth hormone treatment in critically ill adults. $\mathrm{N}$ Engl $\mathrm{J}$ Med, 1999;341:785-792.

09. Annane D, Melchior JC - Hormone replacement therapy for the critically ill. Crit Care Med, 2003;31:634-635.

10. Carroll PV, Van den Berghe G - Safety aspects of pharmacological GH therapy in adults. Growth Horm IGF Res, 2001;11:166-172.

11. Demling R - Growth hormone therapy in critically ill patients. N Engl J Med, 1999;341:837-839.

12. Gardelis JG, Hatzis TD, Stamogiannou LN et al - Activity of the growth hormone/insulin-like growth factor-I axis in critically ill children. J Pediatr Endocrinol Metab, 2005;18:363-372.

13. Balcells J, Moreno A, Audi L et al - Growth hormone/insulin-like growth factors axis in children undergoing cardiac surgery. Crit Care Méd, 2001;29:1234-1238.

14. Pons Leite H, Gilberto Henriques Vieira J, Brunow De Carvalho W et al - The role of insulin-like growth factor I, growth hormone, and plasma proteins in surgical outcome of children with congenital heart disease. Pediatr Crit Care Med, 2001;2:29-35

15. Onenli-Mungan N, Yildizdas D, Yapicioglu $\mathrm{H}$ et al - Growth hormone and insulin-like growth factor 1 levels and their relation to survival in children with bacterial sepsis and septic shock. J Paediatr Child Health, 2004;40:221-226.

16. Huysman MW, Hokken-Koelega AC, Hop WC et al - Effect of dexamethasone treatment on serum GH, IGF-I, and the binding proteins IGFBP-1 and -3 in ventilated very preterm infants. Pediatr Res, 2003;54:37-43.

17. de Groof F, Joosten KF, Janssen JA et al - Acute stress response in children with meningococcal sepsis: important differences in the growth hormone/insulin-like growth factor I axis between nonsurvivors and survivors. J Clin Endocrinol Metab, 2002;87:3118-3124.

18. Review Manager (RevMan) [Computer program]. Version 4.2 for Windows. Copenhagen: The Nordic Cochrane Centre, The Cochrane Collaboration, 2003.

19. Awaddalla S, Cabeza N, Pachon C - Uso de la hormona de crecimiento humana como coadyuvante en el manejo de la de la sepsis en niños. Actual Pediatr, 2000;10:118-121.

20. Gilpin DA, Barrow RE, Rutan RL et al - Recombinant human growth hormone accelerates wound healing in children with large cutaneous burns. Ann Surg, 1994;220:19-24.

21. Herndon DN, Barrow RE, Kunkel KR et al - Effects of recombinant human growth hormone on donor-site healing in severely burned children. Ann Surg, 1990;212:424-431.

22. Jeschke MG, Barrow RE, Herndon DN - Recombinant human growth hormone treatment in pediatric burn patients and its role during the hepatic acute phase response. Crit Care Med, 2000;28:1578-1584.

23. Ramirez RJ, Wolf SE, Barrow RE et al - Growth hormone treatment in pediatric burns: a safe therapeutic approach. Ann Surg, 1998;228:439-448.

24. Hart DW, Herndon DN, Klein G et al - Attenuation of posttraumatic muscle catabolism and osteopenia by long-term growth hormone therapy. Ann Surg, 2001;233:827-834.

25. Suman OE, Thomas SJ, Wilkins JP et al - Effect of exogenous growth hormone and exercise on lean mass and muscle function in children with burns. $J$ Appl Physiol, 2003;94:2273-2281.

26. Chrysopoulo MT, Jeschke MG, Ramirez RJ et al - Growth hormone attenuates tumor necrosis factor alpha in burned children. Arch Surg, 1999;134:283-286.

27. Klein GL, Wolf SE, Langman CB et al - Effects of therapy with recombinant human growth hormone on insulin-like growth factor system components and serum levels of biochemical markers of bone formation in children after severe burn injury. J Clin Endocrinol Metab, 1998;83:21-24

28. Sheridan RL, Schnitzer JJ - Management of the high-risk pediatric burn patient. J Pediatr Surg, 2001;36:1308-1312.

29. Herndon DN, Pierre EJ, Stokes KN et al - Growth hormone treatment for burned children. Horm Res, 1996;45:(Suppl1):29-31.

30. Prelack K, Dwyer J, Sheridan $\mathrm{R}$ et al - Body water in children during recovery from severe burn injury using a combined tracer dilution method. J Burn Care Rehabil, 2005;26:67-74.

31. Murphy KD, Lee JO, Herndon DN - Current pharmacotherapy for the treatment of severe burns. Expert Opin Pharmacother, 2003;4:369-384.

32. Herndon DN, Tompkins RG - Support of the metabolic response to burn injury. Lancet, 2004;363:(9424):1895-1902.

33. Herndon DN, Ramzy PI, DebRoy MA et al - Muscle protein catabolism after severe burn: effects of IGF-1/IGFBP-3 treatment. Ann Surg, 1999;229:713-722. 